\title{
Frontline Interview
}

\section{Whistleblowers inside the Australian building racket}

\section{ABSTRACT}

Multiple Walkley Award winners Nick McKenzie and Richard Baker from Fairfax's Melbourne newspaper, The Age, have rocked venerable Australian institutions to their foundations with their investigative reporting. Previous investigations have exposed drug smuggling within Australian Customs, bribery on behalf of the Reserve Bank and organised criminals' manipulation of horse racing. The duo started this year with an investigation deemed worthy of a Royal Commission. Their reports across the Fairfax network and on the ABC's 7.30 programme featured interviews with whistleblowers risking their lives to go on the record to publicise the relationship between Construction Forestry Mining and Energy Union (CFMEU) and organised crime. The stories also exposed registered businesses owned by major organised crime figures winning lucrative construction contracts from the Victorian state government, and dealings within the New South Wales government's Barangaroo development. Freelance reporter and University of Technology, Sydney, Journalism Masters student Lawrence Bull spoke with Nick McKenzie and Richard Baker about their latest project in two careers full of influential investigations, 'Inside the Building Racket'.

Keywords: Australia, building industry, corruption, investigative journalism

$Y$

TOU SAY in your reports that corruption in the building industry has been around for years. I'm guessing you were aware of it well before research?

you started this investigation. What was the spark that started your

Nick McKenzie: It's been a very long running project of ours because corruption has been so entrenched in the building industry. Although what's 


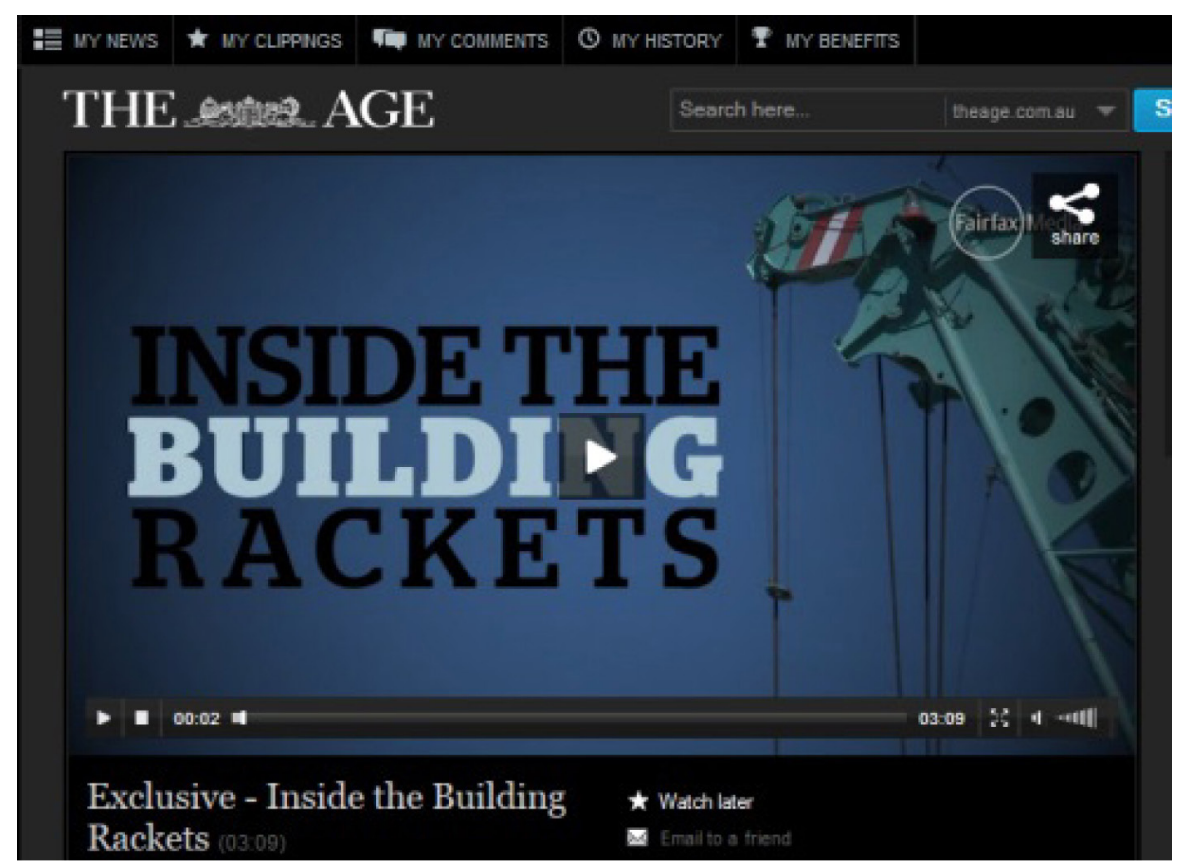

Figure 1: The Inside the Buildings Rackets multimedia series in The Age.

happened lately - there's been a spike of organised crime and especially bikie involvement in the building industry, often overlapping with the operations of the construction union-the CFMEU. So we've been looking at this for ten years. In the last year or so, we developed a number of very critical inside sources who've allowed us to follow a bit of a money trail and confirm and corroborate the fact that organised crime was thriving in the building industry in New South Wales and Victoria, and that bribes and inducements were being paid in rackets involving both union officials and building companies.

But was it a tip off, or did you guys start the investigation of your own volition?

Nick McKenzie: Well, as I said, we've honestly been looking at this for ten years. So there's not been a singular tip-off or anything like that, it's been a long running area of interest because it's such a corrupt industry. And just through years of cultivating sources and keeping an eye on things, we 
began to - or, we found ourselves in a situation about a year ago - to begin to corroborate what we suspected to be the case, and that was that there was large-scale corruption, bribery, secret commission, standover, involvement of organised crime figures - bikies, those sorts of things. So it didn't arrive like a letter in the mail or a single phone call. It's been really a ten-year investigation that reached critical mass about a year ago, allowing us to report the way we did a few weeks back.

Richard Baker: And often there's no magic behind the timing of the publication. It's often got to do with the workload here or when you've got enough free time to dedicate to doing the work and doing it properly. So, there's no mystery to when things appear, it's just when you get enough space and time to do it properly.

So, in a sense, is this a continuation on from your wharfie investigations, and other union-related corruption?

Nick McKenzie: Only to the extent that the construction industry and the waterfront-maritime industry are both really susceptible, really vulnerable to organised crime and corruption, and as investigative reporters we're drawn to sectors of our society that host corruption. So, similarly, we've looked at white-collar crime involving large companies paying bribes overseas, in great detail. These are areas of huge vulnerability, and where there's vulnerability, where there's money, where there's power, there'll be corruption. So, there's no overlap specifically, other than those broad themes between those two industries. But it's fair to say that in a small town like Melbourne or Sydney, when you're looking at organised crime you'll find an organised crime figure who's involved with the construction unions and in the construction industry will often have an involvement on the waterfront as well.

So Mick Gatto has very good contacts on Melbourne's waterfront. Police suspect he takes a fee for arranging the movement of containers through Melbourne's waterfront. He's also notorious for working as an industrial relations fixer in Melbourne's - and Sydney's - construction industry. So he's across both sectors.

How did you go about establishing the network of relationships between unions, crime figures and construction companies? 
Nick McKenzie: Just through old-fashioned reporting. Speaking to people who would tell us that Company A was, while on the paperwork looked like it was controlled by $\mathrm{Mr} \mathrm{X}$, it was in fact controlled by Mr Y, and if we dug a bit deeper we could uncover that. Sure enough, Mr Y was a known organised crime figure, and if we dug a bit deeper we would see a relationship with a union official. And ultimately we got a lot of background information through court cases, through business ASIC searches, through faceto-face source cultivation and corroboration, and then by convincing some key union officials to go on camera, and people who've borne witness to corruption or extortion, to tell their stories publicly, which was a huge step for them to take. And they really put the meat on the bone. They put their credibility on the line and they said, 'Well, this is what's been going on'.

How much of this investigation involved speaking to sources as opposed to sourcing documents?

Nick McKenzie: Eighty percent involved speaking to sources. Actually, no, probably 60 to 70 percent is speaking to sources. And 30 percent is background, so the paper research I guess - court cases, ASIC searches, landtitle searches, bankruptcy searches, those sorts of things.

Richard Baker: And those documents are particularly important when you have a number of sources who are willing to say stuff off background, but for various reasons don't want to be identified or don't want to have their name to things. It's all well and good hearing that in that capacity, but if you can't establish the link with hard-copy documents and other evidence like that, that makes it much harder to for you to write anything.

Was it difficult to get sources to speak?

Nick McKenzie: Of course it is, because the price of speaking out about this sort of stuff can be loss of business, or in extreme cases you can get bashed or killed. The construction industry has a lot of heavy characters, so people don't rush to speak out about a corrupt union official or someone like Mick Gatto because these people have a lot to lose and are known for using, in some cases, violence to get their way.

So it was tough in some respects. Ninety-nine percent of our sources for these stories are background sources, because they own building companies 
or they work for a union and they want to keep their jobs and they're concerned about their safety. Luckily one of our key sources, Brian Fitzpatrick, the union official who went on the record - he's a tough guy, he's 70 years old, so I think he's at the stage in his life where he's willing to stand up and be counted in a really brave fashion. But that's very unusual. Most people stay in the background for good reason.

Were you concerned for your safety?

Nick McKenzie: No, we don't live in Russia or China, places like that, where journalists are routinely bashed or killed. It's a huge step for a crime figure or a corrupt person to threaten a journalist or to do something to a journalist. They know if they were to do that - to harm a journalist or their family - there would be a lot of, one would hope, police attention and community outcry. These people want to lurk in the shadows. Those who are most vulnerable are our sources. They hold the keys that let us open the doors, and there are people who want to shut them up. So in this investigation three or four of our critical sources have been given very serious threats against their safety, against their family, against their lives, against their businesses - and that's a huge concern.

But neither of you were threatened personally?

Nick McKenzie: You cop the odd blunt phone call, but there's been no serious threat to our safety. No.

Why has the scrutiny by police and other government agencies into this corruption been so poor?

Nick McKenzie: Well, corruption is often behind the scenes, it's under the surface. So it's not rearing its ugly face up, it's not on the front pages of the paper. Victims are very unwilling to come forward because, if you're the victim of a standover or you're a witness to a bribe, then it's likely that you yourself are tainted or you yourself have been threatened.

Richard Baker: It's hard to prove.

Nick McKenzie: Yeah, so there's people naturally won't come forward. Police and regulatory agencies are unfortunately, in this country, largely 
reactive agencies. So they act when a complainant comes forward in reaction to something. They're not proactive, they're not going out digging and doing the things that you need to do - tapping phones, putting listening devices in, running coercive hearings - speaking to people that you need to do to uncover behind-the-scenes corruption. It's also very expensive for police forces to do that-resource intensive. And often the result, the bangfor-the-buck, is not that great. So, unfortunately the disinterest by the law enforcement and regulatory bodies across Australia has allowed corruption to become entrenched and endemic in the construction industry.

Inciting a response from regulatory agencies has been an issue for you guys in the past, but this time the print had barely dried on your stories before the Prime Minister announced a royal commission into union corruption. Did you expect such a powerful reaction?

Nick McKenzie: The government had flagged that it would do some sort of a Royal Commission into the union movement at some point. I guess we didn't expect... no one knows what the reaction is going to be, but we did know that the corruption we were exposing was very serious and something would have to be done about it. Especially because law-enforcement and regulation had failed, drastically failed, up until now. No one knows what form exactly the Royal Commission will take, what sort of investigations it will run, how far and how deep it will investigate. So while it's heartening to know there's going to be a large-scale investigative response-I'm still waiting to see what rocks it will lift up and how deep it will go. I mean, at the moment, the police know there's people who are paying bribes, who have paid bribes.

There's evidence of bribery, and the police have not got off their bums to go and find it, for a whole range of reasons, which is extraordinarily disappointing. In Melbourne or Sydney you can pay a bribe in the building industry and be pretty confident you'll get away with it, unfortunately. So the Royal Commission, if it starts to look at that, then terrific. But the Royal Commission in some respects is limited to union corruption, so that may have the effect... A lot of the bribery takes place outside of the union movement.

Now what about that bribery? Will that be looked at? So while the Royal Commission is a welcome response in some respects, the proof will be in the pudding. 
You did a piece about Greens South Australian Senator Penny Wright, who's moved an inquiry into Australia's ability to tackle corporate corruption and fraud (Greens senator Penny Wright calls for corruption inquiry, The Age, 12 February 2014). This would follow up your previous investigations as well as this current one. How important is this to you, compared to the Royal Commission?

Richard Baker: It goes hand-in-hand. The Royal Commission is one thing, but obviously a factor of the stories and the reports that's been there through this investigation with the building industry and unions, but also other things, into white-collar stuff, has been Australia's inability to expose and tackle corruption through law enforcement. Our record in investigating and prosecuting foreign bribery, for example, is far poorer than that of the US and the UK, and that's something that Australia needs to lift its game on, and that's what that Greens motion is about.

So do you think such an inquiry would be equally important to a commission into union corruption?

Richard Baker: Well, it's important in its own right, and they're different things. The union corruption thing is very specific and quite targeted and this other one's looking across a number of agencies and across an international perspective, and historically about Australia's performance in the sector, and probably, hopefully, coming up with some recommendations about how we could do things better. They're both important.

When you put an investigation like this out there and governments pay attention, like occurred in this instance, are you worried about losing control of framing the story?

Richard Baker: No, not at all. We can't control what other people do or how they respond to our stories. All we can control is what we report, and whatever happens off the back of that is nothing - it's out of our hands. No, it's not an issue for us.

The government response to this investigation was much more powerful than, say, the response to the Dirty Money' investigation, which really took years to get off the ground (www.theage.com.au/interactive/2011/national/ 
securency/index.html). Was that motivating for you guys? Was that inspiring to see?

Richard Baker: Let's be upfront about this: it's politics - how governments respond, Labor or Liberal. That's just the way it is. Obviously when you've got a conservative government in power that's already flagged it's going to be digging into the union movement for a variety of reasons, and one of those reasons is because it's going to cause pain to their political opponents, let's not be shy about it. Of course they're going to jump on things like this quickly. Equally, when you're writing stories about venerable institutions like the Reserve Bank of Australia, which has a number of very wellconnected business people on its board and former Liberal Party officials and things like that, right in the guts of some of the stories we were doing there, there's going to be a reluctance because no one wants to embarrass the Reserve Bank of Australia. You've just got to be realistic about it, and be pretty upfront. That's how it is. Politics has a big say in how these things are responded to. And again: we can't help that. We just do the stories. It's not up to us how governments respond.

Now, this investigation you broke, pretty much in tandem with the $A B C$. How important was that?

Nick McKenzie: It's an important story for the Australian public, so it was good that it was across the Fairfax network-The Financial Review, The Age, The Sydney Morning Herald, The Canberra Times... There's a lot of people reading it. But also, the $\mathrm{ABC}$ has a really powerful reach across the country, and one of the critical things about the involvement of broadcast is when one of our sources, Brian Fitzpatrick, agreed to get in front of the camera and blow the whistle on union corruption. It's powerful to read about it in the paper, but it's far more powerful to watch and hear him tell his story on camera. It's something that the print, while it has a lot of great advantages in journalism, there's nothing that can replicate the power of a television interview when you've got a great whistleblower. So that was really great, to have the $\mathrm{ABC}$ on board, willing to put its resources, its journalists onto the story to check and corroborate facts and also to use its very powerful platform like the 7:30 programme to broadcast this important man's story.

PACIFIC JOURNALISM REVIEW 20 (2) 2014169 
Is that something that you've learned from previous investigations - the crucial relationship with the ABC, or, perhaps not crucial, but is that something that you're more likely to do in the future-to 'break' stories with in tandem with the $A B C$ ?

Nick McKenzie: We've done it in the past. We've been doing it since 2009. We do a Four Corners once or twice a year, 7:30 Reports ... I think I've done four Four Corners and four or five 7:30 Reports major stories. So that's something that's well established. We've got a good relationship and it's one we hope to continue because it empowers the journalism, and that's what it's all about. It's about getting as many people to watch, hear, to read the story, and to understand what's at stake, as possible. It's all about maximising story impact.

\section{References}

Chronology - Fairfax: 'Inside the Building Racket'

Inside the Building Rackets [video], January 27, 2014 http://media.theage.com.au/ news/national-news/exclusive--inside-the-building-rackets-5110341.html

Crime-linked companies win work on Victorian state projects, January 28, 2014 www.smh.com.au/national/crimelinked-companies-win-work-on-victorian-stateprojects-20140127-31iyp.html\#ixzz2wYYjG7yG

Bribery, dirty deals rife in building industry, January 28, 2014 www.theage.com.au/ national/bribery-dirty-deals-rife-in-building-industry-20140127-31j0a.html

Union veteran received death threats, January 28,2014 www.theage.com.au/national/ union-veteran-received-death-threats-20140128-31 kuw.html\#ixzz2wYKdRcE8

Another top union official forced out, January 30, 2014 www.theage.com.au/national/ another-top-union-official-forced-out-20140129-31n7e.html\#ixzz2wYLTCulf

Harry Triguboff's company Meriton faced extortion attempt, January 31, 2014

www.theage.com.au/national/harry-triguboffs-company-meriton-faced-extortionattempt-20140130-31pqf.html\#ixzz2wYMQoCAb

Major firms caught in scams, February 1, 2014 www.theage.com.au/victoria/majorfirms-caught-in-scams-20140131-31srz.html\#ixzz2wYb7PoOo

Union bribes revealed, February 10, 2014 www.theage.com.au/national/union-bribesrevealed-20140209-32a3n.html

Australia one of most expensive places to build, February 12, 2014 www.theage.com. $\mathrm{au} /$ federal-politics/political-news/australia-one-of-most-expensive-places-to-build20140211-32g2g.html\#ixzz2wYbyLHxi

Greens senator Penny Wright calls for corruption inquiry, February 12, 2014 www. theage.com.au/federal-politics/political-news/greens-senator-penny-wright-callsfor-corruption-inquiry-20140211-32g2i.html 
Former police union boss Paul Mullet alleged to be in plot to take control, February 17,2014 www.theage.com.au/victoria/former-police-union-boss-paul-mullet-alleged-tobe-in-plot-to-take-control-20140216-32ty3.html\#ixzz2wYcnTKjf

CFMEU organiser arrested for trespass, February 25, 2014 www.theage.com.au/federalpolitics/political-news/cfmeu-organiser-arrested-for-trespass-20140225-33e $7 \mathrm{v} . \mathrm{html}$

Construction union whistleblowers warned not to cooperate with corruption investigators, February 26, 2014

www.theage.com.au/federal-politics/political-news/construction-union-whistleblowers-warned-not-to-cooperate-with-corruption-investigators-20140225-33fsw. html\#ixzz2wYJ6G8cO

Crime figure hired Labor power-broker Graham Richardson to lobby developers, March 3, 2014

www.theage.com.au/national/crime-figure-hired-labor-powerbroker-graham-richardson-to-lobby-developers-20140302-33u1f.html\#ixzz2wYIpFgGV

Bikie gangs muscle in on car wash businesses, March 10, 2014

www.theage.com.au/victoria/bikie-gangs-muscle-in-on-car-wash-businesses20140309-34fj3.html\#ixzz2wYIftA9R

\section{ABC: 7.30 Report}

Insider reveals crime and corruption in Australia's construction industry, January 28, 2014 www.abc.net.au/7.30/content/2013/s3937937.htm?site=kimberley

Whistleblower reveals experience of union intimidation, January 29, 2014 www.abc. net.au/7.30/content/2013/s3934404.htm

Lawrence Bull is a radio reporter and producer on the CBAA, 2ser and FBi; freelance journalist; and Journalism Masters student at the University of Technology, Sydney.

lawrence.bull@gmail.com

PACIFIC JOURNALISM REVIEW 20 (2) 2014171 